\title{
DISTANCE LEARNING IN TRADITIONAL HIGHER EDUCATION: A REFLECTION ON BRAZILIAN LEGISLATION AND THE WILLINGNESS AND PERCEPTION OF BENEFITS OF MANAGEMENT STUDENTS
}

\author{
Anna Cristina Pascual Ramos, Carlos Eduardo Munhoz \\ and Marcileide Muniz Cavalcante de Melo Silva \\ University of Santo Amaro, Brazil
}

\begin{abstract}
The present work aims to verify the willingness and the perception of benefits to the formation from the perspective of the students of the superior management courses, traditional modality, to attend curricular units in the distance learning - DL. The resistance of students in face-to-face courses to the proposition of distance learning units naturally occurs because students chose to study in the traditional mode. However, Brazilian law has encouraged the inclusion of distance learning units in face-to-face courses, allowing up to $40 \%$ of the workload to be integrated at a distance. The methodology is exploratory from the perspective of the survey of the Brazilian legislation that supports the expansion of the integration of the workload taught at a distance in face-to-face courses and also quantitative considering the results of a instrument, measured on the Likert scale, applied to 100 students in face-to-face courses at three different Universities. In the management area, in Higher Education Institutions - HEI with administrative characteristics and different levels of distance content insertion. The work shows that students have less resistance to distance learning, when the HEI have already consolidated the inclusion of distance learning in traditional courses. Students also point to a scenario in which distance learning can offer benefits to their education and learning. The work to verify that depending on the phase or level of insertion of DL in the Institutions, student resistance may be reduced and the benefits may be better realized.
\end{abstract}

\section{KEYWORDS}

Distance Learning, Higher Management Courses

\section{INSERTION OF DISTANCE LEARNING UNITS IN TRADITIONAL COURSES}

The research was applied through a questionnaire instrument, measured by the Likert scale to students from three Higher Education Institutions - HEIs, from administrative categories and different levels of distance content insertion: University - level 3 (already consolidated insertion of EAD content), University Center - level 2 (Initial insertion of EAD content) and Faculty - level 1 (no insertion of EAD content).

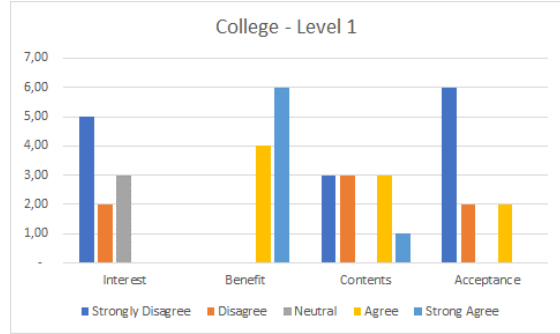

Graph 1. Faculty Results - DL insertion Level 1 Source: the authors 
We can observe that in the college where distance content is not yet offered in face-to-face courses, there is a significant resistance to distance learning, which would in some way have benefits to the students' education and learning.

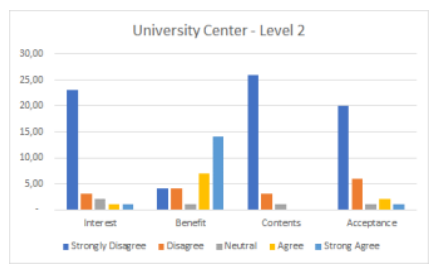

Graph 2. University Center Results - DL insertion Level 2

Source: the authors

In the case of the University Center where the distance learning content is being implemented in the faceto-face courses, we can also notice a low interest of students in the course, even though they recognize the benefits of distance learning for their education.

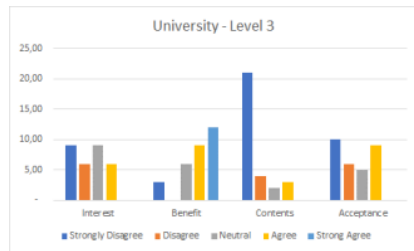

Graph 3. University Results - DL insertion Level 3 Source: the authors

We note that the interest of students enrolled in the University considered level 3 in the insertion of distance learning content in face-to-face courses is more balanced compared to students in HEIs level 1 and 2. Most students also recognize the benefits for their education and learning.

\section{CONSIDERATIONS}

The work through the exploratory methodology shows evident the intentionality on the part of the government in the expansion of DL, including in the face-to-face courses. The results of the research show that in fact students have lower resistance to distance learning, when the HEIs have already consolidated the insertion of distance learning in traditional courses. In this sense, the work is important for the HEIs that do not yet offer content in the distance learning modality and those that begin the implementation of the modality in face-to-face courses. The choice of curricular units or content can be decisive in the acceptance of students, the perception of benefits and also in the reduction of resistance and increased interest on the part of students to study distance learning. The work does not exhaust the possibility of analysis and in-depth studies on the subject since the distance learning modality is a trend in Brazilian education.

\section{REFERENCES}

Alves, L. Educação à distância: conceitos e história no Brasil e no mundo. Disponível em: <http://www.abed.org.br/revistacientifica/Revista_PDF_Doc/2011/Artigo_07.pdf >. Acesso em: 15 set. 2019.

Amorim, M. F. A importância do ensino à distância na educação profissional. Disponível em: <file:///C:/Users/aramos/Downloads/3218-13509-1-PB\%20(1).pdf> Acesso em: 17 ago. 2019.

Arruda, E. \& Arruda, D. Educação À distância no Brasil: Políticas Públicas e Democratização do acesso ao Ensino Superior. Educação em Revista. Julho-Setembro 2015.

INEP. Divulgação dos Resultados CENSO da Educação Superior de 2018. Boletim 19 de setembro de 2019.

Litto, F. \& Formiga, M. (Org.). Educação a distância: o estado da arte. São Paulo: Pearson Education do Brasil, 2009.

Moran, J. M. Aperfeiçoando os modelos de EAD existentes na formação de professores. Disponível em: <file:///C:/Users/aramos/Downloads/5775-19041-1-PB.pdf>. Acesso em: 17 ago. 2019. 